\title{
Microwave power level and exposure time alteration of compost tea efficacy, and growth of Plectranthus amboinicus
}

\begin{abstract}
The unique properties of selective heating at the molecular level, and the resultant enhancement effect of microwave in agri-food sciences have been amply demonstrated. This study examined variations in microwave irradiation power level $(0,100,200,300$ and $400 \mathrm{~W}$ ) and exposure times (5 and $10 \mathrm{~min}$ ) effects on the potency of municipal solid waste (MSW) compost tea and Plectranthus amboinicus plant growth and nutrient composition. A linear regression equation showed slopes of $0.160^{\circ} \mathrm{C} / \mathrm{W}$ for the $10 \mathrm{~min}$ exposure and $0.114^{\circ} \mathrm{C} / \mathrm{W}$ for the $5 \mathrm{~min}$ exposure. The turbidity of the microwaved compost tea reduced as the microwave power level and exposure increased. Electric conductivity, total dissolved solids and salinity of the MSW compost tea increased by a factor of 0.08 at the $400 \mathrm{~W}$ power level. Plant sap ${ }^{\circ}$ Brix, nitrate and calcium concentrations were increased by power levels of $\geq 300 \mathrm{~W}$. Stem diameter was increased by an average factor of 0.08 for the $5 \mathrm{~min}$ and 10 min exposure times following application of the $300 \mathrm{~W}$ microwaved MSW compost tea. Chlorophyll content rose by a factor of 0.09 at 10 mins between the $200 \mathrm{~W}$ and the $300 \mathrm{~W}$ after which it remained unchanged. On the other hand, anthocyanin content was consistently higher in plants treated with the 5 mins microwaved MSW compost tea compared to the 10 mins treatment irrespective of the microwave power level. To understand the mechanism of action of microwaved vermicast, current study is focused on microbial communities in MSW compost tea.
\end{abstract}

Keywords: microwave irradiation, compost, organic amendment, Plectranthus, plant nutrition
Volume 3 Issue 4 - 2019

\author{
Hanchu Yu, Ekene Mark-Anthony Iheshiulo, \\ Lokanadha Rao Gunupuru, Lord Abbey \\ Faculty of Agriculture, Department of Plant, Food, and
} Environmental Sciences Dalhousie University, Canada

Correspondence: Lord Abbey, Faculty of Agriculture, Department of Plant, Food, and Environmental Sciences, Dalhousie University, 50 Pictou Road, Truro B2N 5E3, Nova Scotia, Canada, Email loab07@gmail.com, LAbbey@Dal.Ca

Received: July 19, 2019 | Published: July 23, 2019

\section{Introduction}

Application of microwave technology in agriculture has gained considerable research attention due to its unique selective heating at the molecular level. ${ }^{1,2}$ The electromagnetic wave of microwave irradiation has frequency of approximately $2.45 \mathrm{GHz}$, which is higher than radio waves but lower than infrared waves. ${ }^{2}$ The principle of operation of microwave technology is based on rapid movement of polar (water) molecules leading to collisions and friction that generate localized super heating. ${ }^{2,3}$ As such, the quantitative and qualitative effects of microwave irradiation are dependent on various factors such as power output level, exposure time, and the moisture content and heat capacity of the exposed material. These determine heat-load and extent of alteration in the properties of the exposed material. However, the effect of microwave irradiation on the efficacy of compost tea and plant growth performance is unknown.

The efficacy and importance of municipal solid waste compost are well documented, especially in improving soil structure, crop productivity and enhancing action transfer. ${ }^{4-6}$ Nevertheless, the major concern is the potential release of heavy metals and other solid contaminants from municipal solid waste compost into soils and environment. For that matter, source separation is used to minimize contaminants, ${ }^{7}$ while microwave technology was successfully used to extract heavy metals from sewage sludge. ${ }^{8}$ It is therefore worthwhile to investigate the use of microwave technology to enhance quality and efficacy of municipal solid waste compost tea while minimizing potential environmental hazards.

Plectranthus amboinicus, also known as Jamaican thyme, Mexican mint and others, is popularly used as ornamental, culinary and medicinal plant in the tropics. It is valued for its bioactive compounds for the treatment of fever, skin diseases and control of diabetes mellitus. ${ }^{9,10}$ Plectranthus amboinicus is also used for flavoring beef, chicken, and goat meats to mask their strong smells. ${ }^{11}$ Recent study indicated that vermicompost can enhance growth, antioxidants and anti-Streptococcus properties of Plectranthus amboinicus. ${ }^{12}$ Water extracts and infusion of composts are becoming popular foliar spray or soil drench in the agricultural industry. For instance, diluted leachate of vermicompost was used to minimize leaf scorching and other physical damages, and to increase plant growth. ${ }^{13}$ Based on these previous studies, it was postulated that an increase in microwave irradiation power output level and time of exposure will enhance compost tea nutrient density to improve plant growth and nutrients uptake. Therefore, the objectives of this study were to determine variations in microwave power level and exposure time alteration of physical and chemical properties of municipal solid waste compost tea, and to assess its impact on Plectranthus amboinicus growth and nutrients uptake.

\section{Materials and Methods}

\section{Location and materials}

The experiment was performed in the Department of Plant, Food, and Environmental Sciences greenhouse from March to August 2017. Municipal solid waste compost was obtained from Fundy Compost Inc., Brookfield, NS, Canada. Soft-wood cuttings of Plectranthus amboinicus were obtained from a healthy mother plant in the department's greenhouse. Promix BX ${ }^{\mathrm{TM}}$ soilless potting mix medium (Premier Horticulture Inc., Quakertown, PA, USA) was purchased from a local retailer (Halifax Seeds Company, Debert, NS, Canada). 
The Promix $\mathrm{BX}^{\mathrm{TM}}$ was a general-purpose peat-based substrate composed of $75 \%-85 \%$ sphagnum peat moss; horticultural-grade perlite and vermiculite; dolomitic and calcitic limestone; a wetting agent, and mycorrhizal fungus (Glomus intraradices). A General Electric Microwave Oven (Model No. JES1295STC01, Mabe Canada Inc., Mississauga, ON, Canada) was used to irradiate the MSW compost tea.

\section{Rooting of stem cuttings and planting}

Approximately, 5-cm length soft-wood stem cuttings of the Plectranthus amboinicus each with three buds were planted in a 36 cell-tray filled with perlite alone in March 2017. Before planting, the stem-end of each cutting was dipped in STIM ROOT \#1 (i.e. 0.1\% indole-3-butyric acid) to promote rooting. The cuttings were placed in the nursery under mist irrigation system for two weeks to root. After rooting, plants were moved to the main growing area of the greenhouse to establish. The rooted cuttings were transplanted into 6-inch diameter plastic pots (i.e. one plant per pot) containing 500 $\mathrm{g}$ of Promix $\mathrm{BX}^{\mathrm{TM}}$ soilless mix alone. The plants were watered once every two or three days with distilled water. No additional nutrient supplement nor compost was added throughout the growing period. The mean temperature in the greenhouse was approximately $24^{\circ} \mathrm{C}$ during the day and $18^{\circ} \mathrm{C}$ at night, and a mean relative humidity of approximately $78 \%$. Supplementary lighting was provided using a $600 \mathrm{~J} \cdot \mathrm{s}^{-1}$ high-pressure sodium lamp to achieve a 12-hr light cycle when needed. Plants were harvested 16 weeks after transplanting.

\section{Preparation and application of MSW compost tea}

One-hundred (100) g of dry MSW compost at approximately $10 \%$ moisture content was placed in a conical flask and 21 of distilled water and a magnetic stirrer were added. The mixture was stirred for $24 \mathrm{hr}$ using Isotemp stirring plate (model LT1892X1, Thermo Fisher Scientific Inc., Markham, ON, Canada) to make a MSW compost extract referred to as MSW compost tea. The compost tea (2001) was then microwaved at varying microwave power levels and exposure times in a microwavable pyrex glass bowl. The microwave power levels were 100,200, 300 and $400 \mathrm{~W}$ at exposure times 5 and 10 mins. The control treatment was non-microwaved compost tea $(0 \mathrm{~W})$. The microwaved MSW compost teas were allowed to cool down before analysis and drenching of the respective growing media. Each pottedplant received $40 \mathrm{ml}$ of the respective compost tea once every two weeks.

\section{Experimental design and data collection}

The 2-factor experiment consisted of six different levels of microwave power output levels and two different times of exposure to irradiation (see section 2.3 above). The treatments were arranged in a randomized complete block design with five replications. Time was the main plot and the microwave power level was the subplot. Each treatment combination or experimental unit consisted of five potted plants. The pots were rearranged weekly to offset any unpredictable occurrence due to variation in greenhouse environment that might influence the results.

\section{MSW compost tea and growing medium analysis}

The temperature of the microwaved MSW compost tea was recorded immediately after the microwave irradiation treatment. The turbidity of the microwaved MSW compost tea was recorded using a Turbidity meter (Oakton Instruments, IL, USA). Total dissolved solids
(TDS), electric conductivity (EC) and salinity of the microwaved MSW compost tea was recorded using Oakton PCTesterTM 35 multimeter (Oakton Instruments, IL, USA). Nitrate $\left(\mathrm{NO}^{3-}\right)$, potassium $\left(\mathrm{K}^{+}\right)$, sodium $\left(\mathrm{Na}^{+}\right)$and calcium $\left(\mathrm{Ca}^{2+}\right)$ ion concentrations were determined using LAQUA Twin ion meter (HORIBA. Minami-ku, Kyoto, Japan). At the end of the experiment, 10-g samples of the individual growing medium per treatment were liquefied in $40 \mathrm{ml}$ distilled water, stirred for 5 mins and the $\mathrm{EC}, \mathrm{TDS}, \mathrm{NO}^{3-}, \mathrm{K}^{+}, \mathrm{Na}^{+}$and $\mathrm{Ca}^{2+}$ concentrations were determined as previously described. The same data as described above for the microwaved MSW compost teas were collected for the control treatment i.e. non-microwaved MSW compost tea.

\section{Leaf tissue analysis}

Leaves $(50 \mathrm{~g})$ of Plectranthus amboinicus were harvested from the third youngest leaf cluster for sap extraction using hydraulic plant sap press (Spectrum Technologies Inc, Aurora, Illinois, USA) and analyzed. ${ }^{\circ}$ Brix was determined using a portable PAL-BX/RI ATAGO refractometer (ATAGO USA Inc., WA., USA). Also, the concentrations of $\mathrm{NO}^{3-}, \mathrm{Na}^{+}$and $\mathrm{Ca}^{2+}$ were determined as previously described.

\section{Leaf pigments and plant growth analyses}

Chlorophyll content was estimated by SPAD value of leaf greenness from the $3^{\text {rd }}$ and $4^{\text {th }}$ youngest leaf per plant per treatment using SPAD 502 Chlorophyll meter (Spectrum Technologies Inc., Aurora, Illinois, USA). Anthocyanin content was also determined from the same tagged leaves using ACM-200 plus (Opti-Science Inc., Hudson, USA). Plant growth was estimated using stem diameter and total plant fresh weight at final harvest. The stem diameter was measured from the mid-section of the stem using a pair of Mastercraft calipers (Canadian Tire. Toronto, ON, Canada).

\section{Data analysis}

Data collected were subjected to a two-way analysis of variance (ANOVA) using Proc Mixed in SAS version 9.4 (SAS Institute Inc., Cary, NC). Fisher's least significant difference (LSD) test was used for mean comparison at an $\alpha$-level of $5 \%$ when ANOVA showed significant difference at $\mathrm{P} \leq 0,05$ between treatments. Microsoft Excel was used to plot graphs to show trends and cause and effect relationships.

\section{Results and discussion}

Heat-load as measured by temperature of the MSW compost tea rose linearly as the microwave power output level was increased from 0 to $400 \mathrm{~W}$, irrespective of the time of exposure (Figure 1). The longer the exposure time, the higher the temperature of the MSW compost tea. It was found that the mean temperature of the MSW compost tea was $45^{\circ} \mathrm{C}$ at the 5 mins exposure and $58^{\circ} \mathrm{C}$ at the $10 \mathrm{mins}$ exposure. Microwave energy output (E) is directly proportional to electromagnetic wave frequency (f) in the equation $E=f x h$; where $\mathrm{h}$ is Plank constant. ${ }^{14}$ As such, an increase in power output level will increase the electromagnetic wave frequency and therefore, the heatload of the exposed mass as observed in the present study. The linear regression equations in Fig. 1 showed highly significant $(\mathrm{P}<0.01)$ coefficient of regression $\left(\mathrm{R}^{2}\right)$ values of approximately, 0.95. The slopes indicated rate of change in temperature per unit power level, which was higher in MSW compost tea at the $10 \mathrm{mins}\left(0.160^{\circ} \mathrm{C} / \mathrm{W}\right)$ of exposure compared to the $5 \operatorname{mins}\left(0.114^{\circ} \mathrm{C} / \mathrm{W}\right)$ of exposure. 


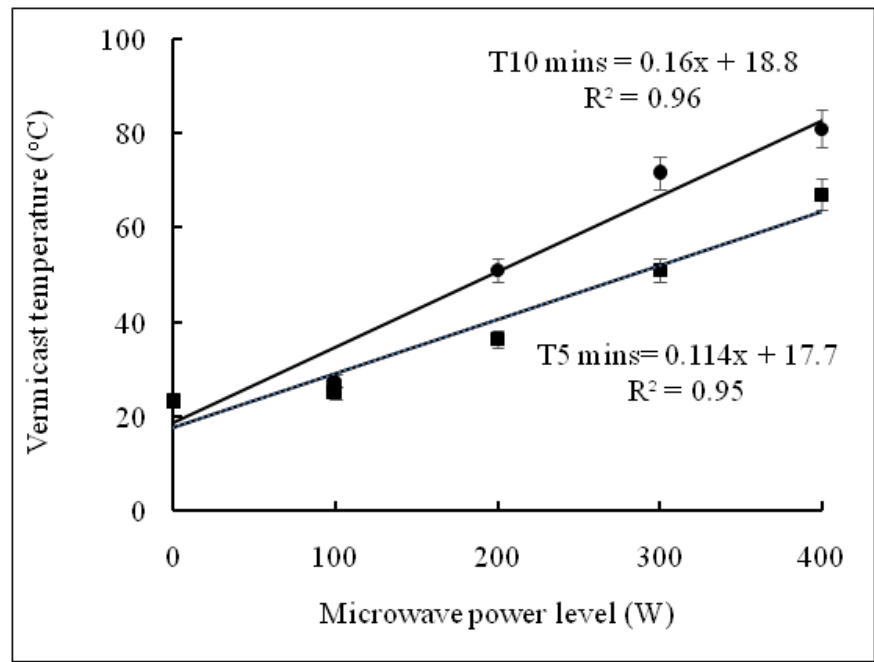

Figure I Compost tea temperature as affected by variations in microwave power output level and exposure time ( $\mathbf{\square}, 5$ mins; $\bullet$, 10 mins).

Almost all of the quality parameters of the MSW compost tea were significantly $(\mathrm{P}<0.001)$ affected by the microwave power level, exposure time and their interaction (Table 1). Turbidity was used to assess the clarity of the compost tea. As the microwave power level increased from 100 to $400 \mathrm{~W}$ or the exposure time was increased from 5 mins to 10 mins, the turbidity of the compost tea significantly $(\mathrm{P}<0.00)$ reduced to clarity. The turbidity was not different between the $0 \mathrm{~W}$ (i.e. control, no microwave) and the $100 \mathrm{~W}$ or the $300 \mathrm{~W}$ and the $400 \mathrm{~W}$ treatments. It was previously suggested that carbonation or charring of organic matter occurs as microwave power level was increased to $\geq 400 \mathrm{~W}$ at which the temperature of the material rose to $80^{\circ} \mathrm{C} .^{15,16}$ Therefore, the continuous reduction in turbidity as the power level was increased in the present study can be attributed to increased carbonation of the compost tea rose (Figure 1).

The trends in the EC, TDS and salinity of the MSW compost tea were similar (Table 1). Values of these three quality parameters increased slightly from the 0 to the $200 \mathrm{~W}$ treatment by a factor of 0.02 (Table 1). The EC, TDS and salinity then increased rapidly to their peak values by a factor of 0.08 at the $400 \mathrm{~W}$ power level. This pattern conformed to previous observation by Abbey et al. ${ }^{17}$ They found that TDS and EC values were increased to a peak when microwave power level was increased from 0 to $400 \mathrm{~W}$ at 5 mins exposure time. TDS and EC are associated with total mineral nutrients, which were found to be consistently higher in the MSW compost tea microwaved at $400 \mathrm{~W}$ for $10 \mathrm{~min}$. The rapid collision and friction amongst polar molecules in addition to the increased temperature may have disrupted microbial cells and bio-labile compounds. These might have altered the chemistry of the MSW compost tea. As such, $\mathrm{NO}^{3-}$, $\mathrm{K}^{+}, \mathrm{Na}^{+}$and $\mathrm{Ca}^{2+}$ were increased at higher microwave power levels and extended time of exposure (Table 1). $\mathrm{Ca}^{2+}$ concentration was not affected by differences in exposure time. Hendricks and Pascoe ${ }^{18}$ Demonstrated the use of microwave irradiation for increasing soil nutrients from dead microbial cells. They reported that microwaved soil generated more carbon dioxide-carbon, nitrogen, phosphorus and organic-carbon when $300 \mathrm{~g}$ of soil samples were heated at $700 \mathrm{~W}$ for 20 mins. Furthermore, Song et al. ${ }^{19}$ reported that varied exposure times to microwave irradiation increased density of predominant soluble solids. These may be the reason behind the trends in the EC, TDS, salinity and ionic concentrations of the MSW compost tea in the present study.

Table I Compost tea properties as affected by variations in microwave power level and exposure time

\begin{tabular}{|c|c|c|c|c|c|c|c|c|}
\hline Treatments & $\begin{array}{l}\text { Turbidity } \\
\text { (NTU) }\end{array}$ & $\begin{array}{l}\text { Electric conductivity } \\
(\mu S \mathrm{~cm}-\mathrm{I})\end{array}$ & $\begin{array}{l}\text { Total dissolved } \\
\text { solids (mg I-I) }\end{array}$ & $\begin{array}{l}\text { Salinity } \\
\text { (mg I-I) }\end{array}$ & $\begin{array}{l}\mathrm{K}+(\mathrm{mg} \\
\mathrm{I}-\mathrm{I})\end{array}$ & $\begin{array}{l}\text { NO3- } \\
\text { (mg I-I) }\end{array}$ & $\begin{array}{l}\mathrm{Na}+ \\
(\mathrm{mg} \mid-\mathrm{I})\end{array}$ & $\begin{array}{l}\mathrm{Ca} 2+ \\
(\mathrm{mg} \mathrm{I}-\mathrm{I})\end{array}$ \\
\hline \multicolumn{9}{|c|}{ Microwave power output level (W) } \\
\hline 0 & $4.23 a$ & $426.00 \mathrm{e}$ & $302.33 \mathrm{e}$ & $174.33 \mathrm{e}$ & $37.33 c$ & $103.00 \mathrm{e}$ & $28.33 d$ & $15.00 c$ \\
\hline 100 & $4.24 \mathrm{a}$ & $428.67 d$ & $304.00 d$ & $175.17 d$ & $38.00 c$ & $206.67 d$ & $29.33 c$ & I4.67c \\
\hline 200 & $3.36 b$ & $434.00 c$ & $307.67 c$ & I77.67c & $37.83 \mathrm{c}$ & $221.67 c$ & $29.83 c$ & $16.33 b$ \\
\hline 300 & $2.04 \mathrm{c}$ & $446.83 b$ & $317.33 b$ & $183.17 b$ & $42.67 \mathrm{~b}$ & $266.67 b$ & $30.67 b$ & $17.50 \mathrm{a}$ \\
\hline 400 & $1.68 c$ & $468.67 a$ & $332.67 a$ & 192.00a & $44.33 \mathrm{a}$ & $360.00 \mathrm{a}$ & $32.33 a$ & $17.17 \mathrm{a}$ \\
\hline \multicolumn{9}{|c|}{ Time of exposure (mins) } \\
\hline 5 & $3.56 \mathrm{a}$ & $432.93 b$ & $307.13 b$ & I 77.27b & $38.93 b$ & $205.93 b$ & $29.47 b$ & $16.20 \mathrm{a}$ \\
\hline 10 & $2.67 \mathrm{~b}$ & $448.73 a$ & $318.47 a$ & $183.67 \mathrm{a}$ & $41.13 a$ & $257.27 a$ & $30.73 a$ & $16.07 \mathrm{a}$ \\
\hline Power level & $<0.001$ & $<0.001$ & $<0.001$ & $<0.001$ & $<0.001$ & $<0.001$ & $<0.001$ & $<0.001$ \\
\hline Time & $<0.001$ & $<0.001$ & $<0.001$ & $<0.001$ & $<0.001$ & $<0.001$ & $<0.001$ & ns \\
\hline Interaction & 0.017 & $<0.001$ & $<0.001$ & $<0.001$ & $<0.001$ & $<0.001$ & 0.003 & 0.005 \\
\hline
\end{tabular}

NTU, nephelometric turbidity units; means followed by different letters within columns are significantly different at P<0.05 according to Fisher-protected least significant difference test at $\alpha=0.05$.

$400 \mathrm{~W}$ treated growing media compared to those of the $200 \mathrm{~W}$ and $300 \mathrm{~W}$ treatments. It appeared the less disturbance of organic matter and microbial population in the control $(0 \mathrm{~W})$ and the 100 $\mathrm{W}$ treatments may have increased rhizosphere activities such as the release of exudates from the microbes and roots. As the power level increased to $200 \mathrm{~W}$ and $300 \mathrm{~W}$, the high temperatures of the MSW compost tea (Figure 1) probably destabilized the microorganisms and the organic matter content. The high MSW compost tea temperature of $67^{\circ} \mathrm{C}$ for the 5 mins and $81^{\circ} \mathrm{C}$ for the 10 mins at microwave power level of 400 resulted in the highest TDS and EC. Two important effects of such high temperatures on microbial populations might be electrolyte leakage and thermal hydrolysis of bio-labile compounds, which might be the cause of the high TDS and EC in the MSW compost tea. 
The initial properties of the MSW compost tea (Table 1) had an impact on the residual properties of the respective growing media that they were added to (Table 2). The trend in residual $\mathrm{NO}^{3-}, \mathrm{Na}^{+}$and $\mathrm{Ca}^{2+}$ concentrations were different compared to the TDS and the EC (Table 2). Overall, an increase in microwave power level increased residual mineral nutrient concentrations. Concentrations of $\mathrm{NO}^{3-}, \mathrm{Na}^{+}$ and $\mathrm{Ca}^{2+}$ residues in the growing medium were highest in the 400 $\mathrm{W}$ treatments but were lowest in the $0 \mathrm{~W}$ and the $100 \mathrm{~W}$ treatments. Growing medium residual $\mathrm{NO}^{3-}$ concentration was similar in the 200, 300 and the $400 \mathrm{~W}$ treatments while $\mathrm{Ca}^{2+}$ concentration was similar in the $200 \mathrm{~W}$ and the $300 \mathrm{~W}$ treatments. Interaction between microwave power level and exposure time had effect on residual chemicals in the growing medium (Table 2). It is well known that EC was associated with soil salinity and soil health, which can usually be influenced by growing medium moisture content and organic materials..$^{20,21}$ TDS is a measure of the aggregate of small organic and inorganic materials in the growing medium or MSW compost dissolved in water. In general, the high microwave power level significantly increased $\mathrm{NO}^{3-}$ and $\mathrm{Ca}^{2+}$ concentrations of the growing medium and altered the growing medium chemical properties and plant growth performance.

Table 2 Growing medium chemical composition as affected by vermicast treated at varying microwave irradiation power level and exposure time

\begin{tabular}{|c|c|c|c|c|c|}
\hline Treatments & Electric conductivity $(\mu \mathrm{S} \mathrm{cm}-\mathrm{I})$ & Total dissolved solids (mg I-I) & NO3-(mg l-I) & $\mathrm{Na}+(\mathrm{mg} \mathrm{l}-\mathrm{I})$ & $\mathrm{Ca} 2+(\mathrm{mg} \mathrm{I}-\mathrm{I})$ \\
\hline \multicolumn{6}{|c|}{ Microwave power output level (W) } \\
\hline 0 & 1373.3a & $920.0 \mathrm{a}$ & $1213.3 \mathrm{c}$ & $158.7 \mathrm{~b}$ & $77.3 c$ \\
\hline 100 & I354.0a & $942.7 \mathrm{a}$ & $3040.0 b$ & $160.7 \mathrm{ab}$ & $75.3 c$ \\
\hline 200 & $1157.3 b c$ & $836.7 \mathrm{bc}$ & 7933.3a & $154.7 \mathrm{~b}$ & $586.7 b$ \\
\hline 300 & $1151.3 c$ & $803.3 c$ & $8000.0 a$ & $140.7 \mathrm{c}$ & $600.0 \mathrm{~b}$ \\
\hline 400 & I274.0ab & $910.0 \mathrm{ab}$ & $8553.3 a$ & $167.3 \mathrm{a}$ & $1113.3 \mathrm{a}$ \\
\hline \multicolumn{6}{|c|}{ Time of exposure (mins) } \\
\hline $5 \mathrm{~min}$ & $1276.0 \mathrm{a}$ & $892.8 \mathrm{a}$ & $5157.3 b$ & $156.0 \mathrm{a}$ & $470.1 \mathrm{a}$ \\
\hline $10 \mathrm{~min}$ & I248.0a & $872.3 a$ & 6338.7a & $156.8 \mathrm{a}$ & $510.9 a$ \\
\hline Power level & 0.001 & 0.004 & $<0.001$ & $<0.001$ & $<0.001$ \\
\hline Time & ns & ns & 0.029 & ns & ns \\
\hline Interaction & ns & ns & ns & ns & ns \\
\hline
\end{tabular}

Means followed by different letters within columns are significantly different at $\mathrm{P}<0.05$ according to Fisher-protected least significant difference test at $\alpha=0.05$

Plectranthus amboinicus leaf sap ${ }^{\circ}$ Brix was highest in plants that received MSW compost tea microwaved at higher power levels of $\geq 300 \mathrm{~W}$ (Table 3 ) but was similarly reduced by the 0,100 and 200 $\mathrm{W}$ treatments. Sap concentrations of $\mathrm{NO}^{3-}$ and $\mathrm{Ca}^{2+}$ were high in the 200,300 and $400 \mathrm{~W}$ treated plants compared to the 0 and $100 \mathrm{~W}$ treated plants. Leaf sap concentration of $\mathrm{Na}^{+}$was highest in plants grown in the $400 \mathrm{~W}$ followed by the 100,200 and $300 \mathrm{~W}$, and the least was recorded by plants grown in the $0 \mathrm{~W}$ treatment. Overall, plants grown in the $0 \mathrm{~W}$ treatment had the least concentrations of all the mineral nutrients, while time of exposure of the MSW compost tea to microwave irradiation did not affect sap ${ }^{\circ}$ Brix and concentrations of $\mathrm{NO}^{3-}, \mathrm{Na}^{+}$and $\mathrm{Ca}^{2+}$.

Table 3 Leaf chemical status of Plectranthus amboinicus as affected by variations in microwave power level and exposure time

\begin{tabular}{|c|c|c|c|c|}
\hline Treatments & oBrix & NO3-(mg I-I) & $\mathrm{Na}+(\mathrm{mg} \mathrm{l}-\mathrm{I})$ & $\mathrm{Ca} 2+(\mathrm{mg} \mathrm{I}-\mathrm{I})$ \\
\hline \multicolumn{5}{|c|}{ Microwave power output level (W) } \\
\hline 0 & $0.70 \mathrm{~b}$ & $1500.00 \mathrm{~b}$ & $93.00 c$ & $110.00 c$ \\
\hline 100 & $0.77 \mathrm{~b}$ & $1536.67 b$ & $109.83 \mathrm{ab}$ & $120.00 \mathrm{~b}$ \\
\hline 200 & $0.75 b$ & $2966.67 a$ & $108.33 \mathrm{ab}$ & I40.00a \\
\hline 300 & $0.85 \mathrm{a}$ & $3016.67 a$ & $99.33 \mathrm{bc}$ & $136.67 \mathrm{a}$ \\
\hline 400 & $0.85 a$ & $3266.67 a$ & $111.50 \mathrm{a}$ & 145.00a \\
\hline \multicolumn{5}{|c|}{ Time of exposure (mins) } \\
\hline 5 & $0.80 \mathrm{a}$ & $2473.33 a$ & $105.00 \mathrm{a}$ & $131.33 a$ \\
\hline 10 & $0.77 \mathrm{a}$ & 2441.33 aа & $103.80 \mathrm{a}$ & $129.33 a$ \\
\hline Power level & 0.002 & $<0.001$ & 0.011 & $<0.001$ \\
\hline Time & ns & ns & ns & ns \\
\hline Interaction & 0.038 & 0.002 & ns & ns \\
\hline
\end{tabular}

Means followed by different letters within columns are significantly different at $\mathrm{P}<0.05$ according to Fisher-protected least significant difference test at $\alpha=0.05$ 
Pigmentation (i.e. chlorophyll and anthocyanin contents) was more responsive and varied at the 5 mins exposure time compared to the 10 mins exposure time across the different microwave power levels (Figure 2). At $100 \mathrm{~W}$, the $5 \mathrm{~min}$ exposure remarkably reduced Plectranthus amboinicus leaf tissue chlorophyll content but rose to a peak value at $200 \mathrm{~W}$ before declining slightly at power levels $\geq 300 \mathrm{~W}$ (Figure 2, upper panel). On the other hand, chlorophyll content of the Plectranthus amboinicus was similar for treatments 0,100 and $200 \mathrm{~W}$ at the 10 mins exposure time.
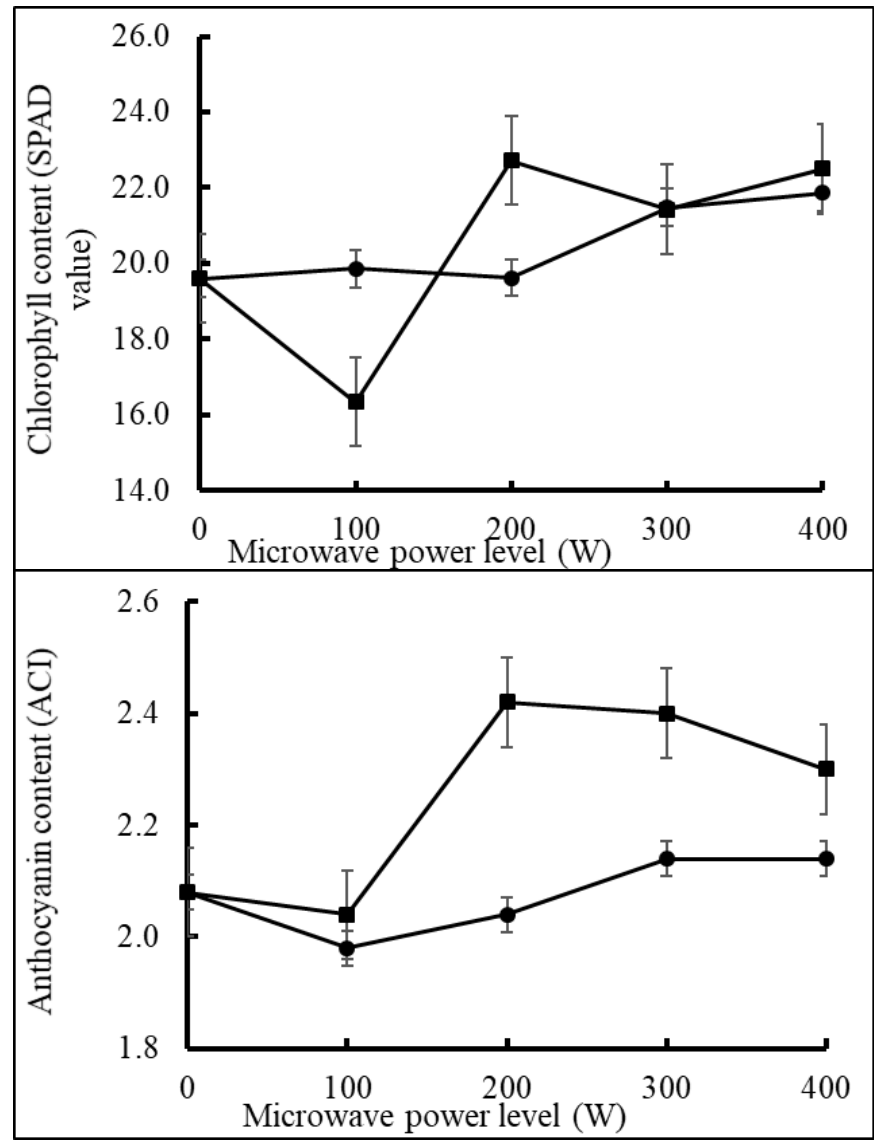

Figure 2 Chlorophyll (upper panel) and anthocyanin content (lower panel) of Plectranthus amboinicus as affected by variations in microwave power level and exposure time ( $\mathbf{\square}, 5$ mins; $\bullet, 10$ mins).

Instead, chlorophyll content rose by a factor of 0.09 at 10 mins between the $200 \mathrm{~W}$ and the $300 \mathrm{~W}$ after which it remained unchanged. Anthocyanin content was consistently higher in plants treated with the 5 mins microwaved MSW compost tea compared to the 10 mins treatment (Figure 2, lower panel). There was a sharp (i.e. 18\%) increase in anthocyanin content from the $100 \mathrm{~W}$ to the $200 \mathrm{~W}$ treatment exposed at 5 mins of microwave irradiation before it declined slightly when the power level was further increased to $400 \mathrm{~W}$. For the 10 mins treatment, there was a slight reduction in anthocyanin content before it gently rose between the $100 \mathrm{~W}$ and the $300 \mathrm{~W}$ treatments. Thus, anthocyanin content of the Plectranthus amboinicus plants was significantly $(\mathrm{P}<0.05)$ increased when the MSW compost tea was microwaved at $\geq 200 \mathrm{~W}$ for 5 mins as compared to all the other treatment combinations. Perhaps, the $100 \mathrm{~W}$ treatment might have altered bioavailability of essential nutrients, which affected pigmentation. Hence, the overall similarity or slightly higher values of the chlorophyll and anthocyanin contents recorded in the control non-microwaved MSW compost tea treated plants compared to that of the $100 \mathrm{~W}$ treatment. These two pigments are used as vital signs for plant health and tissue nutrient status. Chlorophyll is essential for photosynthesis and energy generation while anthocyanin affects plant eco-physiological strategies to resist environmental stress, ${ }^{22}$ which include edaphic stress.

Plant sap $\mathrm{NO}^{3-}$ or $\mathrm{Ca}^{2+}$ concentration was positively correlated with growing medium $\mathrm{NO}^{3-}$ and $\mathrm{Ca}^{2+}$ concentrations with an average $\mathrm{r}^{2}$ value of $0.97(\mathrm{P}<0.01)$ or $0.94(\mathrm{P}<0.01)$. On the other hand, strong negative correlation existed between the growing medium $\mathrm{EC}$ and plant sap $\mathrm{NO}^{3-}\left(\mathrm{r}^{2}=-0.81, \mathrm{P}<0.05\right)$ and $\mathrm{Ca}^{2+}\left(\mathrm{r}^{2}=-0.76, \mathrm{P}<0.05\right)$ concentrations. Also, strong positive association between plant sap $\mathrm{Ca}^{2+}$ and $\mathrm{NO}^{3-}\left(\mathrm{r}^{2}=0.97, \mathrm{P}<0.05\right)$ or plant sap $\mathrm{Ca}^{2+}$ and ${ }^{\circ} \mathrm{Brix}\left(\mathrm{r}^{2}=0.75\right.$, $\mathrm{P}<0.05)$ was found. These correlations suggested that alterations in MSW compost tea chemical composition influenced plant nutrient uptake. Response pattern of plant stem diameter to MSW compost tea microwaved at varied power levels were similar for the 5 mins and the 10 mins exposure times (Fig. 3, upper panel).

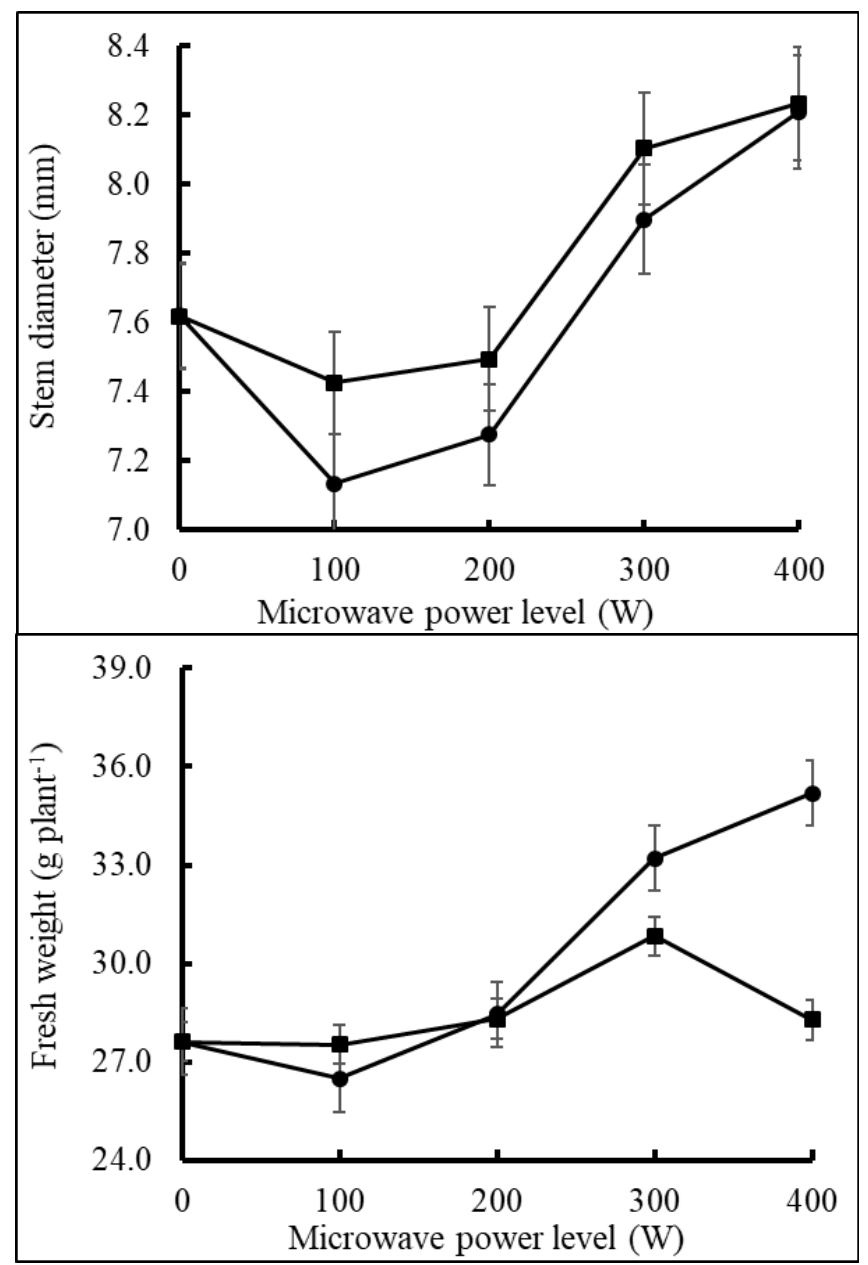

Figure 3 Stem diameter (upper panel) and plant fresh weight (lower panel) of Jamaican thyme (Plectranthus amboinicus) as affected by variations in microwave power level and exposure time ( $\mathbf{\square}, 5$ mins; $\bullet$, 10 mins).

Stem diameter of Jamaican thyme plants were reduced following treatment with the $100 \mathrm{~W}$ microwaved MSW compost tea but increased slightly by the $200 \mathrm{~W}$ treatment. Stem diameter was increased by an average factor of 0.08 for the 5 mins and 10 mins exposure times following application of the $300 \mathrm{~W}$ microwaved MSW compost tea. 
The difference in stem diameter between the 5 mins and the 10 mins exposure times was visually obvious but statistically minimal (Figure 3) (upper panel). Treatments 0,100 and $200 \mathrm{~W}$ for both the 5 mins and the 10 mins exposure times gave similar harvested plant fresh weight (Figure 3) (lower panel). However, MSW compost tea treatments differences for plant fresh weight became apparent after the $200 \mathrm{~W}$ treatment (Figure 3) (upper panel). There was a steep increase in plant fresh weight from $200 \mathrm{~W}$ and $300 \mathrm{~W}$, irrespective of exposure time. However, the slope was steeper for the 10 mins exposure time that that of the 5 mins exposure time.

\section{Conclusion}

Microwave technology can be safely used in the compost industry to enhance the physicochemical properties and efficacy of compost tea, as suggested by the present findings. The technology is currently widely used to sterilize growing media and food, and to extract active principles from agri-food products and byproducts. It was found that microwaved MSW compost tea showed higher potency than non-treated MSW compost tea. It was also found that time of exposure can influence the physical properties, chemical composition and efficacy of compost tea. There is the possibility of charring at higher microwave power levels and exposure time. For instance, charring at the harshest condition i.e. $400 \mathrm{~W}$ and 10 mins reduced turbidity or total particulate matter in the MSW compost tea but still increased total ionic concentration. As such, the critical microwave power level and exposure time will have to be determined for different processing volumes. In the present study, microwave irradiation treatment at power level $400 \mathrm{~W}$ and 10 min exposure time offered the highest nutrients concentrations and increased the overall health of Plectranthus amboinicus plants, growth and yield components. The results also indicated that the $200 \mathrm{~W}$ at 5 min exposure time improved leaf tissue chlorophyll and anthocyanin contents compared to all the other treatments. Microbiological community is a vital factor in organic amendments. Therefore, further studies should focus on the effects of microwave irradiation on microbial communities in MSW compost tea.

\section{Funding}

This research benefitted from funding provided by Compost Council of Canada.

\section{Acknowledgment}

The authors wish to thank Fundy Compost Inc., Brookfield, NS for providing the municipal solid waste compost for the study and Ms. Krista MacLeod for providing technical assistance for the greenhouse operation.

\section{Conflicts of interest}

The authors declare that there is no conflict of interest.

\section{References}

1. Remya N, Lin JG. Current status of microwave application in wastewater treatment-a review. Chem Eng J. 2011;166:797-813.

2. Li T, Yang Q. Advantages of diffuse light for horticultural production and perspectives for further research. Frontiers in Plant Sci. 2015;6:704.

3. Mandal V, Mohan Y, Hemalatha S. Microwave assisted extraction of curcumin by sample-solvent dual heating mechanism using taguchi 19 orthogonal design. J Pharm Biomed Anal. 2008;46:322-327.
4. Mandal M, Chandran RS, John C. Sencindiver. Amending subsoil with composted poultry litter-i: effects on soil physical and chemical properties. Agronomy. 2013;3(4):657-669.

5. Herrera F, Castillo J, Chica A, et al. Use of municipal solid waste compost as a growing medium in the nursery production of tomato plants. Biore Technol. 2008;99:287-296.

6. Abbey L, Annan N, Asiedu SK, et al. Amino acids, mineral nutrients, and efficacy of vermicompost and seafood and municipal solid wastes composts. Intl J Agron. 2018;1-6.

7. Avramidou P, Evangelou A, Komilis D. Use of municipal solid waste compost as a growth media for an energy plant (rapeseed). $J$ Environ Manage. 2013;121:152-159.

8. Cid BP, Albores AF, Gómez EF, et al. Use of microwave single extractions for metal fractionation in sewage sludge samples. Anal Chimica Acta. 2001;431:209-218

9. Abdel-Mogib M, Albar H, Batterjee S. Chemistry of the genus Plectranthus. Molecules. 2002;7:271-301.

10. Arumugam G, Swamy MK, Sinniah UR. Plectranthus amboinicus (lour.) spreng: Botanical, phytochemical, pharmacological and nutritional significance. Molecules. 2016;21:369.

11. Lukhoba CW, Simmonds MS. Paton AJ. Plectranthus: A review of ethnobotanical uses. J Ethnopharm. 2006;103:1-24.

12. Zhang B, Wijesundara NM, Abbey L, et al. Growing medium amendments effect on growth, secondary metabolites and anti-streptococcal activity of two species of Plectranthus. J Appl Res Med Arom Plants. 2017;5:53-59.

13. Quaik S, Ibrahim MH. A review on potential of vermicomposting derived liquids in agricultural use. Intl J Sci Res Publ. 2013;3:1-6.

14. Planck MKEL. Zur theorie des gesetzes der energieverteilung im normalspectrum. Verhandl Dtsc Phys Ges. 1900;2:237.

15. Islam K, Weil R. Microwave irradiation of soil for routine measurement of microbial biomass carbon. Biol Fert Soils. 1998;27:408-416.

16. Huang YF, Kuan W, Lo S, et al. Total recovery of resources and energy from rice straw using microwave-induced pyrolysis. Bior Technol. 2008;99:8252-8258.

17. Abbey L, Udenigwe C, Mohan A, et al. Microwave irradiation effects on vermicasts potency, and plant growth and antioxidant activity in seedlings of chinese cabbage (Brassica rapa subsp. Pekinensis). $J$ Rad Res Appl Sci. 2017;10:110-116.

18. Hendricks CW, Pascoe N. Soil mcirobial biomass estimates using 2450 mhz microwave irradiation. Plant and soil. 1988;110:39-47.

19. Song ZX, Wang ZY, Wu LY, et al. Effect of microwave irradiation pretreatment of cow dung compost on bio-hydrogen process from corn stalk by dark fermentation. Intl J Hydr Ener. 2012;37:6554-6561.

20. Phonphan W, Tripathi NK, Tipdecho T, et al. Modelling electrical conductivity of soil from backscattering coefficient of microwave remotely sensed data using artificial neural network. Geocarto Intl. 2014;29:842-859.

21. Rahman MM, Hagare D, Maheshwari B. Framework to assess sources controlling soil salinity resulting from irrigation using recycled water: An application of bayesian belief network. J Cleaner Prod. 2015;105:406419.

22. Garriga M, Retamales JB, Romero-Bravo S, et al. Chlorophyll, anthocyanin, and gas exchange changes assessed by spectroradiometry in fragaria chiloensis under salt stress. J Integ. Plant Biol. 2014;56:505515 . 